\title{
VECTORIAL ELECTRON TRANSFER IN SPATIALLY ORDERED ARRAYS
}

\author{
Progress Report
}

January 1991-December 1991

\author{
Marye Anne Fox \\ Department of Chemistry \\ University of Texas \\ Austin, Texas 78712
}

January 1992

\section{PREPARED FOR THE U.S. DEPARTMENT OF ENERGY UNDER GRANT NUMBER DE-FG05-85ER13387 AMD A007 \\ DISCLAIMER}

\begin{abstract}
This report was prepared as an account of work sponsored by an agency of the United States Government. Neither the United States Government nor any agency thereof, nor any of their employees, makes any warranty, express or implied, or assumes any legal liability or responsibility for the accuracy, completeness, or usefulness of any information, apparatus, product, or process disclosed, or represents that its use would not infringe privately owned rights. Reference herein to any specific commercial product, process, or service by trade name, trademark, manufacturer, or otherwise does not necessarily constitute or impiy its endorsement, recommendation, or favoring by the United States Government or any agency thereof. The views and opinions of authors expressed herein do not necessarily state or reflect those of the United States Government or any agency thereof.
\end{abstract}




\section{Report Narrative:}

\section{Progress on "Vectorial Electron Transfer in Spatially Ordered.Arrays (DE- FG05-85ER13387), Jan 1991-Jan. 1992 \\ by Marye Anne Fox

\section{Research Results}

Progress has been made in four areas: a) the synthesis of new materials for directional electron transfer; b) the preparation and characterization of anisotropic composites bearing organic and inorganic components; c) the elaboration of mechanisms of electrocatalysis; and d) the development of new methods for surface modification of metals and semiconductors.

Toward the first objective, several novel classes of materials have been prepared: molecules capable of forming macroscopic charge transfer complexes with potential as organic metals, coordination polymeric semiconductors, liquid crystals, dimensionally controlled conducting organic polymers, and functionalized helical oligopeptides. A new series of tetrathiafulvalene derivatives have been prepared which exhibit interesting magnetic properties and which can function as photoelectrets. ${ }^{1}$ As in the liquid crystals prepared in earlier years of this program, these solid state materials show appreciable persistent polarization under irradiation. The mechanism of charge transport has been investigated in symmetrically substituted liquid crystalline porphyrins by microwave conductivity, ${ }^{2}$ showing that order near the phase transitions can be exploited in the construction of a photoresponsive solid state device. A family of newly prepared organometallic coordination polymers show light responsiveness and activity as semiconductors. ${ }^{3}$ Conductivity has also been measured in a series of conducting organic polymers. The control of the oxidative potential employed during their formation permitted preparation of lamellar anisotropic arrays of polypyrrole when deposited from micellar solution ${ }^{4}$ or in the presence of an oriented liquid crystalline electrolyte. ${ }^{5}$ Similarly, chronoamperometry was used to predict the spatial distribution of monomer units in a grarded conductive pyrrole / thiophene copolymer. 6 A comparison of these macroscopically graded materials with microscopic analogs formed by funtionalization along an oligopeptide backbone is anticipated. The initial work has defined solubility limitations for polyalanines and has shown that electron transfer rate studies can be used as sensitive probes for conformational folding in complex molecules. ${ }^{7}$

Similar synthetic work has been undertaken to construct organic / inorganic composites which show special reactivity deriving from their controlled environment. In 
addition to addressing the influence of an inert support ${ }^{8}$ or a non-homogeneous medium ${ }^{9}$ on the attainable chemistry evolving at an irradiated semiconductor surface, this work has led to the preparation of quantized CdS clusters in micelles, ${ }^{10}$ of composites in which a sensitizer initiates electron transfer over long distances to a $\mathrm{RuO}_{2}$ cluster capable of gas evoluiton, ${ }^{11}$ and of a coupled porphyrin-spacer-viologen supermolecule in which conformational equilibration can be controlled by dispersion within an inverse micelle. ${ }^{12}$ Theoretical work describing electron and energy migration in composite micelles has also been completed. ${ }^{13}$

The search for new redox-activated catalysts has been pursued in three directions. The effect of substitution on the electronic properties of a family of tetraphenylethylenes has revealed that multiple electron transfer catalysis can result from the twisting induced in the parent by single electron oxidation or reduction. ${ }^{14}$ The synthetic utility of bis(dialkylphosphino)benzene nickel (0) as a catalyst for electrochemical coupling of aryl and vinyl halides has been elaborated, ${ }^{15}$ with mechanistic details of the catalysis found to be dependent on the alkyl substitution pattern. ${ }^{16}$

Finally, progress continues in exploring new methods for characterizing chemically modified surfaces. A digital simulation method for describing corrosion and aging of semiconductor surfaces has been described. ${ }^{17}$ Photoresponsiveness of semiconducto:surfaces modified by attachment of polymeric complexants ${ }^{18}$ or photosensitizers ${ }^{19}$ or by exposure to water ${ }^{20}$ has been investigated and the use of such modified surfaces in photoelectrochemical cells has been described. A new thrust in surface modification by binding of self assembled monolayers and mixed monolayers was described in a poster at the annual DOE Solar Photochemistry Research Meeting ${ }^{21}$ and one paper characterizing exchange sites on such modified surfaces has appeared. ${ }^{22}$

\section{References}

1. Marye Anne Fox and Horng-Long Pan, Proceedings, SPIE-The Intenational Society for Optical Engineering, 1991, 1436, 2.

2. Pieter G. Schouten, John M. Warman, Marye Anne Fox, and Horng-long Pan, Nature. 1991, 353, 736 .

3. Marye Anne Fox and Daniel A. Chandler, Adv. Mater. 1991, 3, 381.

4. David M. Collard and Marye Anne Fox, J. Am. Chem. Soc. 1991, 113, 9414.

5. Walter Torres and Marye Anne Fox, Chem. Mater. 1992, in press.

6. Walter Torres and Marye Anne Fox, Chem. Mater. 1992, in press.

7. Mark'S. Meier, Marye Anne Fox, and John R. Miller, J. Org. Chem. 1991, 56, 5380.

8. Marye Anne Fox, Res. Chem. Intermed. 1991, 15, 153.

9. Marye Anne Fox, Top. Curr. Chem. 1991, 159, 68.

10. A.V. Barzykin and Marye Anne Fox, Isr. J. Chem. 1991, submitted for publication.

11. Ute Resch and Marye Anne Fox, J. Phys. Chem. 1991, 95, 6169.

12. Ute Resch, Stephan Hubig, and Marye Anne Fox, Langmuir 1991, 7, 2923. 
13. A.V. Barzykin, N.S. Barzykina, and M.A. Fox, Chem. Phys. 1992, in press.

14. Jennifer Muzyka and Marye Anne Fox, J. Org. Chem. 1991, 56, 4549.

15. Marye Anne Fox, Daniel A. Chandler, and Chang-jin Lee, J. Org. Chem. 1991, 56, 3246.

16. Marye Anne Fox, Daniel A. Chandler, and Evan P. Kyba, J. Coord. Chem. 1992, in press.

17. John M. Martin, Sam P. Perone, N.J. Kiwiet, and Marye Anne Fox, $J$. Electroanal. Chem. 1991, 313, 61 .

18. Marye Anne Fox and Daniel A. Chandler, Macromol. 1991, 24, 4626.

19. Marye Anne Fox and Phillip F. Britt, New J. Chem. 1992, in press.

20. Masakazu Anpo, Katsuichi Chiba, Masanori Tomonari, Salvatore Coluccia, Michel Che, and Marye Anne Fox, Bull. Chem. Soc. Jpn. 1991, 64, 543.

21. David M. Collard and Marye Anne Fox, Proc. 15th DOE Solar Photochem. Res. Conf. 1991, 197.

22. David M. Collard and Marye Anne Fox, Langmuir, 1991,7, 1192.

\section{Publications Acknowledging DOE Support in Calendar 1991}

\section{A. Reprints of Work Described as Submitted for Publication in the 1990 Progress Report.}

"Charge Separation in Functionalized Tetrathiafulvalene Derivatives," Marye Anne Fox and Horng-Long Pan, Proceedings, SPIE-The Intenational Society for Optical Engineering, $1991,1436,2$.

"Semiconductor Particles Included within Supports," Marye Anne Fox, Res. Chem. Intermed. 1991, 15, 153.

"Influence of Linking Alky! Chain Length on Intramolecular Photoinduced Electron Transfer in Bipyridine-Linked Porphyrin- $\mathrm{RuO}_{2}$ Clusters, " Ute Resch and Maryle Anne Fox, J. Phys. Chem. 1991, 95, 6169.

"The Effect of Substituents on the Electrochemistry of Substituted Tetraphenylethylenes," Jennifer Muzyka and Marye Anne Fox, J. Org. Chem. 1991, 56, 4549.

"Photoinduced Electron Transfer from a Surfactant Zinc Porphyrin to Dialkylviclogens in Water-in-oil Microemulsions. Effect of Interfacial Charge," Ute Resch, Stephan Hubig, and Marye Anne Fox, Langmuir 1991, 7, 2923.

"The Use of Electroactive Thiols to Study the Formation and Exchange of Alkanethiol Monolayers on Gold," David M. Collard and Marye Anne Fox, Langmuir, 19!1, 7, 1192.

"Synthesis and Electrochemical Activity of Nickel Phosphine Complexes and Polymers Bound to Electrode Surfaces," Marye Anne Fox and Vaniel A. Chandler, Macrcimol. 1991, 24, 4626.

"Solid State Electrical Conductivity of a Nickel-Phosphine Coordination Polymer, " Marye Anne Fox and Daniel A. Chandler, Adv. Mater. 1991, 3, 381.

"Digital Simulation of the Laser-Induced Open Circuit Photovoltage at the SemiconductorElectrolyte Interface," John M. Martin, Sam P. Perone, N.J. Kiwict, and Marye Anne Fox, J. Electroanal. Chem. 1991, 313, 61. 
"Photoinduced Electron Transfer in Arranged Media," Marye Anne Fox, Top. Curr. Chem. 1991, 159, 68.

"Electrocatalytic Coupling of Aryl Halides with 1,2-Bis(di-2-propylphosphino)benzene Nickel (0)," Marye Anne Fox, Daniel A. Chandler, and Chang-jin Lee, J. Org. Chem. 1991, 56, 3246.

\section{B. Reprints of Papers Not Mentioned in Previous Progress Reports}

"A Lamellar Conducting Polymer by Self-Assembly of an Electropolymerizable Monomer," David M. Collard and Marye Anne Fox, J. Am. Chem. Soc. 1991, 113, 9414.

"Peptide Conformational Distributions as Studied by Electron Transfer Kinetics," Mark S. Meier, Marye Anne Fox, and John R. Miller, J. Org. Chem. 1991, 56, 5380.

"Vectorial Electron Transfer Mediation: Electrochemical Characterization of Self-Assembled Functionalized Redox-Active Monolayers on Gold," David M. Collard and Marye Anne Fox, Proc. 15th DOE Solar Photochem. Res. Conf. 1991, 197.

"Photocatalysis on Native and Platinum-Loaded $\mathrm{TiO}_{2}$ and ZnÖ. Origin of Different Reactivities on Wet and Dry Metal Oxides," Masakazu Anpo, Katsuichi Chiba, Masanori Tononari, Salvatore Coluccia, Michel Che, and Marye Anne Fox, Bull. Chem. Soc. Jpn. $1991,64,543$.

\section{Accepted Papers for Which Reprints are Not Yet Available}

"Influence of Steric Bulk on the Relative Stabili $y$ and Interchangeability of the Various Oxidation States for Nickel Complexed with 1,2-bis(dialkylphosphino) benzene," Marye Anne Fox, Daniell A. Chandler, and Evan P. Kyba, J. Coord. Chem. 1992, in press.

"Electronic Excitation Transport and Trapping in Micellar Systems: Monte Carlo Simulations and Density Expansion Approximati on," A.V. Barzykin, N.S. Barzykina, and N.A. Fox, Chem. Phys. 1992, in press.

"Electrosynthesis of Polypyrrole in a Nematic Liquid Crystal," Walter Torres and Marye Anne Fox, Chem. Mater. 1992, in press.

"Graded Spatial Distribution in Conducting Co-polymers of Pyrrole and Thiphene," Walter Torres and Marye Anne Fox, Chem. Mater. 1992, in press.

"Charge Migration in Columnar Aggregates of Peripherally Substituted Porphyrins," Pieter G. Schouten, John M. Warman, Marye Anne Fox, and Horng-long Pan, Nature. $1991,353,736$.

" Photosensitization of Semiconductor Electrodes by Aidsorbed Polymeric Layers,"Marye Anne Fox and Phillip F. Britt, New J. Chem. 1992, in press..

\section{Papers Submitted for Publication Currently Being Reviewed}


"A Picosecond Study of the Photophysics of CdS Clusters Grown in Situ in Reversed Micelles," A.V. Barzykin and Marye Anne Fox, Isr. J. Chem. 1991, submitted for publication.

III. Invited Lectures dealing Wholly or Partially with DOE-Sponsored Research (calendar 1991): Regular University seminar visits are not included.

Solar '91 Conference: Energy for a Sustainable World, Annual Meeting of the Australia and New Zealand Solar Energy Society, "Photoelectrochemical Solar Energy Conversion: Photocatalytic Oxidation," Adelaide, Australia, Dec 1991.

Symposium on New Reagents in Organic Synthesis in honor of Sir Derek Barton, Southwest Regional American Chemical Society Meeting, "Polymeric Catalysts for the Redcutive Coupling of Aryl and Vinyl Halides," San Antonio, Tx, Oct. 3, 1991.

1991 International Symposium on Organic Reactions, Kyoto, Japan, Aug. 1991, "Synthesis of Spatially Ordered Electron Relays: Charge Transfer in Layered Conducting Polymers, Conducting Co-Polymers, and Redox-active Functionalized Alkylthiols on Gold."

Sandbjerg Meeting ori Organic Electrochemistry, Soc. Chimica Scandinavica, Sandbjerg, Denmark, June 1991, "Electrocatalytic Coupling of Aryl and Vinyl Halides by Monomeric and Polymeric Bisphosphinobenzene Nickel (0)."

15th DOE Solar Phstochemistry Research Conference, Aspen, CO, June 1991, "Vectorial Electron Transfer Mediation: Electrochemical Characterization of SelfAssembled Functionalized Redox-Active Alkyl Thiols on Gold."

Third Annual Symposium on Organic Chemistry, Western New York Section of the American Chemical Society and Occidental Chemical Corporation, June 1991, "Controlling Electron Transfer in Organic Media."

Havinga Lecture, Gorlaeus Laboratoria der Rijksuniversiteit, Leiden, The Netherlands, May 1991,"Oxidative Semiconductor-mediated Photocatalysis."

Symposium on Photochemistry and Photoelectrochemistry of Organic and Inorganic Molecular Thin Films, International Society for Optical Engineering, Los Angeles, Jan. 1991, "Charge Separation in Functionalized Tetrathiafulvalene Derivatives." 

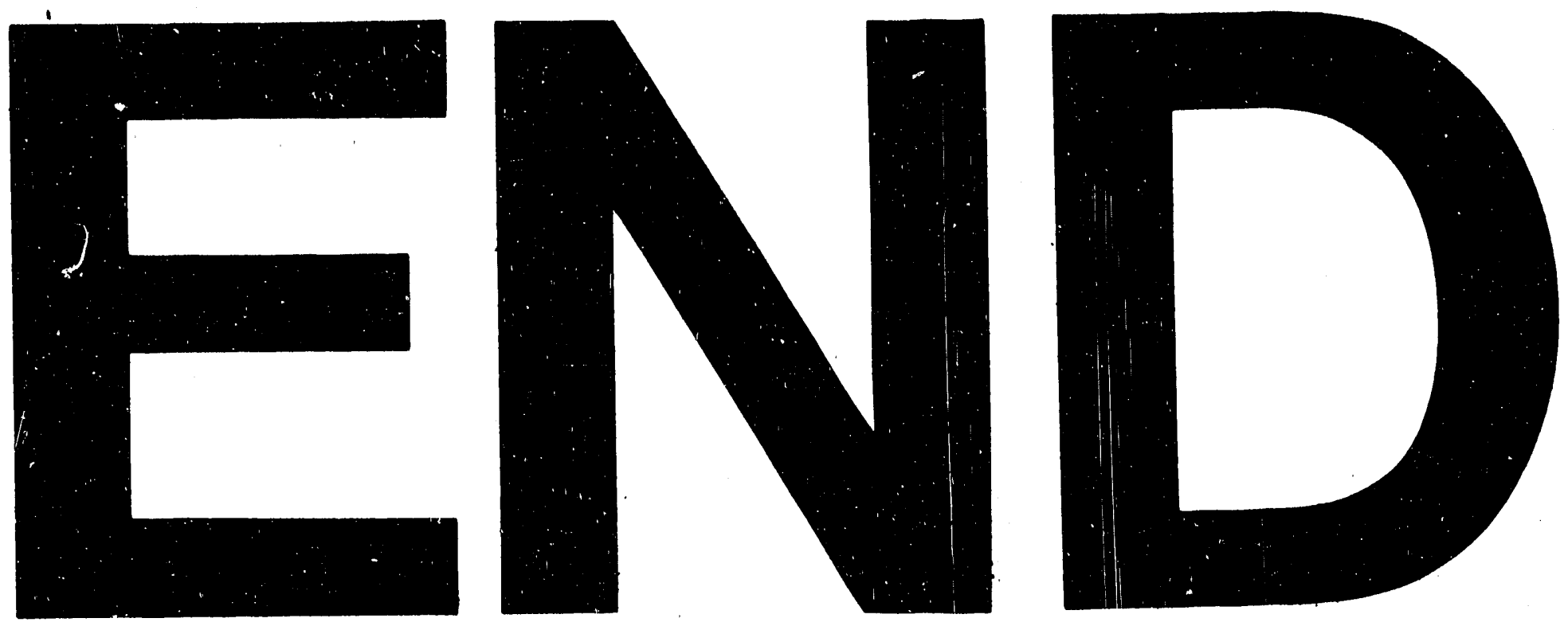

$\exists \operatorname{lin}$
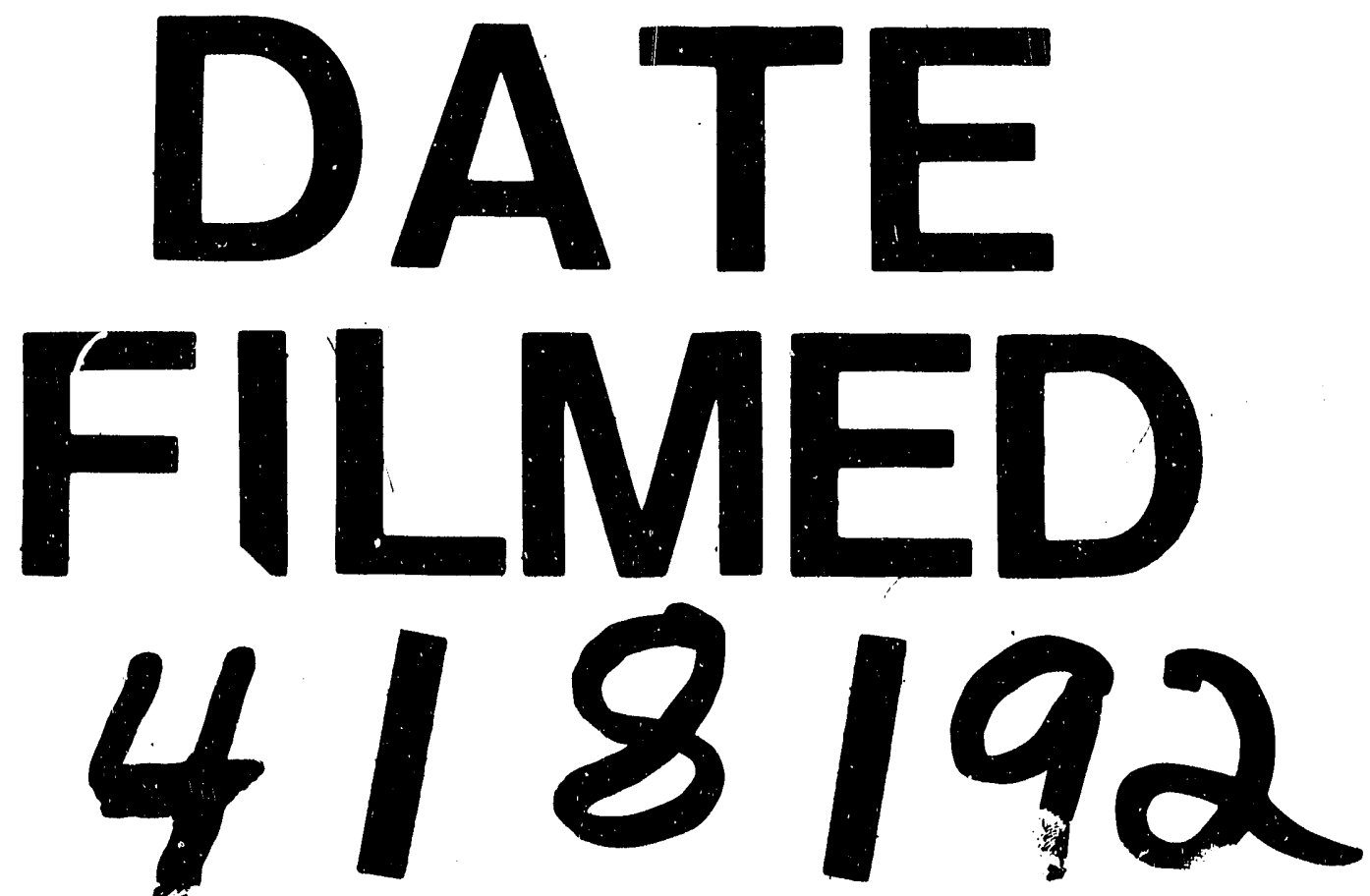

$I$ 
